\title{
Influence Planning and Budgeting Activities on Organizational Performance at Denpasar Bali City Government Bureau
}

I Made Sumada

Associate Professor,

Department of Social and Political Sciences,

Ngurah Rai University, Indonesia
Received: May 17, 2021

Accepted: June 11, 2021

Published: October 1, 2021

Coresponding Authors:

imadesumada@unr.ac.id;

DOI: $10.53947 /$ tspj.v1i1.66

\begin{abstract}
This study aimed to determine the effect of the Planning and Budgeting Activity variables on Organizational Performance at the Denpasar Bali City Government Bureau. Formulation of the problem in the research, namely whether there is an effect of planning and budgeting activities together on organizational performance at Denpasar Bali City Government Bureau. The research method uses a survey with a quantitative correlational approach with a saturated sampling technique. In this study, the number of samples was 37 respondents. Based on the results of the research that has been done, it can be concluded that from the results of the discussion and research, namely: The results of the joint analysis of the influence between planning and budgeting activities on organizational performance conclude that the effect shown by the correlation coefficient $r$ of 0.831 is a very strong positive correlation.
\end{abstract}

Keywords: Planning, Activity Budgeting, Organizational Performance, Denpasar Bali City Government Bureau, Quantitative Method

\section{Introduction}

Realizing the importance of the role of the organization, in this case, the Denpasar Bali City Government Bureau, in achieving development goals, it is necessary to prepare planning and budgeting properly so that all planning and budgeting documents in the regions must remain consistent. Based on the explanation above, this study aims to evaluate the consistency between planning and budgeting documents on organizational performance (Conţu, 2020). The next problem is that government officials still feel a "sectoral ego" in carrying out development activities.

Every agency tends to say that its duties and functions are the most important and the best in development activities. These problems make it difficult to coordinate the preparation of development plans and implementation. The next result is the 
implementation of the development process that is less than optimal, even the expected targets cannot be realized at all (Hanida et al., 2015).

Based on the initial study, the maximum organizational performance has not been achieved at the Denpasar Bali City Government Bureau related to several factors, including planning, budgeting, competence, work ethic, work consistency, and supporting facilities for work activities. However, in this case, these factors are still not optimal in their implementation and implementation in the field. Another factor is the inconsistency of planning documents with budgeting documents; the activity budget plan is not appropriate; organizational performance is not optimal; employee work ethic is still not optimal; employee competence has not met the job qualifications; work facilities are still not complete. All of that can hinder the achievement of organizational performance in the Finance Bureau.

Work planning from year to year does not seem to have the concept of innovation. Then. This relates to setting work goals before carrying out activities, which are the most basic organizational goals. The objective is to determine work policies within the organization, namely to direct the leadership and employees in making decisions; establish work procedures that are by organizational conditions, and handle future organizational problem-solving. Budgeting activities in organizations need to be carried out through expenditure control, so as not to be misdirected or allocate spending to other fields. In addition, budget control has not focused on budget expenditures for activities that are being carried out. For the smooth running of activities, tight and good coordination and communication between work units in the organization has not been seen. Likewise, organizational performance has not been seen to increase by carrying out work activities based on applicable regulations within the organization, the implementation of effective and efficient work activities has not changed significantly.

\section{Methods}

Regarding identifying the problem above, the formulation of the research problem is as follows; Is there any influence of planning on organizational performance at Denpasar Bali City Government Bureau? Second, is there any effect of budgeting activities on organizational performance at Denpasar Bali City Government Bureau? Third, is there any effect of planning and budgeting activities together on Denpasar Bali City Government Bureau?

In this paper, the researcher uses a survey research method with a quantitative approach, which is correlational to see how much influence the independent variables have on the dependent variable, namely the planning and budgeting variables of activities on organizational performance. The study was conducted on a group of individuals, namely employees of Denpasar Bali City Government Bureau. Through this method, the writer hopes to examine specific aspects of a social situation in depth (Ishtiaq, 2019), which is the aspect of the influence of planning and budgeting activities on organizational performance. The drawback of this research method is that because it studies specific aspects, reaching generalizations is very limited. The population in this study were employees of Denpasar Bali City Government Bureau, which had 37 employees. This study uses a quantitative technique, using a saturated sampling technique (Creswell, 2013). In this case, all members of the population are sampled. If the population is 
relatively small, then all members of the population are sampled. The research sample amounted to 37 people.

\section{Theory and Concept}

Planning plays an essential role in achieving development goals on a regional and national scale. Regions, as part of government organizations, must develop plans to achieve development goals by considering the resources they have. Planning is needed because people's desires are unlimited while the available resources (budget) are limited (Gulpenko et al., 2017). The budget is an important instrument for the Government to set priorities for development programs at the regional level. The budget becomes the basis for the agency's financial management for one year, which is the final result of the agency's planning and budgeting process for a full year before the fiscal year (El Dahshan et al., 2018). Planning and budgeting are two things that are closely related. For planning and budgeting to be realistic and on target, it is necessary to be supported by a Government Regulation that outlines the concepts and provisions in more detail regarding the planning and budget framework. Conditions so far indicate that planners tend to ignore documents in planning and budgeting, and there is no linkage between documents (Farr et al., 2006).

In the annual period, there is an organizational work plan, which results from the preparation of a work program plan for a year. Furthermore, the work plan and funding for the organization are used as guidelines in the budgeting process. Budgeting begins with the preparation of a temporary budget program after the information is known about the availability of the budget (Ramdany \& Yadiati, 2018). The preparation of the budget program serves as a document for preliminary discussions that bridge planning and policy and budget drafts based on availability or budget ceilings. Then the agreed interim budget program becomes the guideline for preparing a permanent budget plan (Alain \& Melegy, 2017).

The budget reflects the budget allocation for implementing priority programs and activities agreed in the budget document for one fiscal year. Development plans that receive budget allocations are reflected in expenditure items within the organization. Through spending, the Government produces goods and services aimed at the community (Stevcevska-Srbinoska, 2018). In-Law Number 23 of 2014 concerning Regional Government, it is stated that regional spending is prioritized to protect and improve the quality of people's lives to fulfill regional obligations, which are manifested in the form of improving basic and other services.

From the planning and budgeting documents, the degree of consistency and organizational commitment can be measured or assessed to accommodate priority needs in budget allocation. The existence of consistency between planning and budgeting documents is expected to improve organizational performance in financial management (Bashaer et al., 2016). Failure to maintain the integration and consistency of these documents can have an ineffective impact on the achievement of priority targets and targets for work activities, the performance of public services and ultimately risk the credibility of the organization in carrying out the mandate of national development priorities in the formulation of regional development priorities. Meanwhile, development 
planning in policies, programs, and activities will remain a useless document if it is not linked to other documents.

The budget is a very important part of realizing the development plans and targets set previously. However, on the other hand, budget constraints increasingly require careful planning so that the utilization of available resources is truly carried out effectively and efficiently. Therefore, consistency between planning and budgeting documents is important because it is an indicator in assessing organizational performance. It greatly affects the achievement of the vision, mission, goals, targets, and policies that have been planned in the planning document and have an important role in the implementation of development to improve the welfare of the community through programs aimed at improving the quality of human resources, such as education and training health (Mohammadpour et al., 2016).

The concept of performance can be defined as the level of achievement of results. Performance is the result of a series of process activities carried out to achieve certain goals of an organization. Organizational performance appraisal is considered very important because it can be used as an indicator of the success of an organization in achieving its goals. According to (Risdwiyanto, 2017) performance is a translation of performance which is often interpreted as appearance, demonstration, or achievement. Performance is the level of achievement of organizational goals on an ongoing basis, while according to (Wargadinata, 2017) performance is a description of the level of achievement of the implementation of a program, activity, or policy in realizing the goals, objectives, mission, and vision of the organization contained in the strategic planning of an organization (Taiwo et al., 2016). From some of the opinions above, the concept of performance is a description of the achievement of individuals or groups in an organization in the implementation of activities, programs, and policies to realize the vision, mission, and goals of the organization that have been set arrange (Özdem, 2011).

Indicators that can be used in the implementation of organizational performance measurement are as follows: 1). Input indicators, namely everything that is needed so that the implementation of activities can work to produce outputs, which can be in the form of human resource funds (employees). 2). Process indicators are all quantities that indicate the efforts or activities carried out in the context of processing inputs into outputs. 3). Output indicators are everything that is expected to be used directly from an activity which can be either physical or non-physical. 4). Outcome indicators are everything that reflects the functioning of medium-term activity outputs (direct effects), tangible results from the output of an activity. 5) Benefit indicators are everything related to the ultimate goal of implementing activities, describing the benefits derived from result indicators, showing things that are expected to be achieved if the outputs can be completed and function optimally (right location and time). Indicators of impact, namely the influence that is caused both positively and negatively from the benefits obtained from the results of the activity, can only be known in the medium or long term. It shows the rationale for carrying out activities that describe macro aspects of activity implementation, sectoral, regional, and national activity objectives. Measurement and benefits of organizational performance assessment using existing performance indicators are expected to encourage the achievement of organizational goals and will provide feedback for continuous improvement efforts (Popova \& Sharpanskykh, 2010). 


\section{Discussion}

To determine the effect of planning and budgeting on organizational performance variables, the researchers used analytical calculations as follows:

a. Hypothesis Testing 1

To test the hypothesis, the writer uses product-moment correlation analysis. The product-moment correlation analysis formula is:

$$
r x_{1} y=\frac{\sum x_{1} y}{\sqrt{\left(\sum x_{1}^{2}\right)\left(\sum y^{2}\right)}}
$$

Furthermore, to calculate the correlation value between planning and organizational performance at Denpasar Bali City Government Bureau, the calculation results are as follows:

$$
\begin{aligned}
& r x_{1} y=\frac{\sum x_{1} y}{\sqrt{\left(\sum x_{1}^{2}\right)\left(\sum y^{2}\right)}} \\
& r_{x_{1} y}=\frac{4,391}{\sqrt{(5,357)(5,812)}} \\
& r_{x_{1} y}=\frac{4,391}{\sqrt{31,134}} \\
& r_{x_{1} y}=\frac{4,391}{5,580} \\
& r_{x_{1} y}=0,787
\end{aligned}
$$

Based on the results of these calculations, the correlation coefficient found is 0.787. After consulting this value with the previous interpretation guideline table, it is known that the correlation coefficient is included in the strong positive category because it is between the interval $(0.600-0.799)$. It shows that planning has a positive and strong influence on organizational performance at Denpasar Bali City Government Bureau. Meanwhile, to determine the contribution of planning to organizational performance can be calculated using the following formula:

$$
\begin{array}{rlrl}
\mathrm{kd} & = & \mathrm{r}^{2} \times 100 \% \\
& = & & (0.787)^{2} \times 100 \% \\
& = & 0.619 \times 100 \% \\
= & 61.9 \%
\end{array}
$$

Based on these calculations, it means that planning of $61.9 \%$ affects organizational performance while other factors influence the remaining 38.1\%. Furthermore, to find out whether the influence of planning on organizational performance at Denpasar Bali City Government Bureau is significant or not, it is necessary to test its significance using the $\mathrm{t}$ formula, which is as follows: 


$$
\begin{aligned}
& t=\frac{\mathbf{r} \sqrt{\mathbf{n}-2}}{\sqrt{1-\mathbf{r}^{2}}} \\
& \mathrm{t}=\frac{0,787 \sqrt{37-2}}{\sqrt{1-(0,787)^{2}}} \\
& \mathrm{t}=\frac{4,655}{0,617} \\
& \mathrm{t}=7,544
\end{aligned}
$$

From the results of the above calculations, the t count value of 7.544 is obtained, then this value is compared with the table value for an error of $5 \%$, using a two-part test where $\mathrm{dk}=\mathrm{nk} ; 37-2=35$, and the table value is 2.021 . Based on the results of these calculations, it can be stated that $\mathrm{t}$ count falls in the rejection area of Ho. So it can be concluded that the hypothesis is accepted, meaning that there is an influence between planning on organizational performance of 0.787 , which is strongly positive and significant, meaning that the coefficient can be applied to the entire population.

b. Hypothesis Testing 2

To test the hypothesis, the writer uses product-moment correlation analysis. The product-moment correlation analysis formula is:

$$
r x_{1} y=\frac{\sum x_{2} y}{\sqrt{\left(\sum x_{2}{ }^{2}\right)\left(\sum y^{2}\right)}}
$$

Furthermore, to calculate the correlation value between budgeting activities and organizational performance at Denpasar Bali City Government Bureau, the results of the calculation are as follows:

$$
\begin{aligned}
& r_{x_{1} y}=\frac{4,340}{\sqrt{(5,619)(5,812)}} \\
& r_{x_{1} y}=\frac{4,340}{\sqrt{32,657}} \\
& r_{x_{1} y}=\frac{4,340}{5,715} \\
& r_{x_{1} y}=0,759
\end{aligned}
$$

Based on the results of these calculations, the correlation coefficient found is 0.759 . After consulting this value with the previous interpretation guideline table, it is known that the correlation coefficient is included in the strong positive category because it is between the interval $(0.600-0.799)$. It shows that activity budgeting has a positive and strong influence on organizational performance at Denpasar Bali City Government 
Bureau. Meanwhile, to determine the contribution of budgeting activities to organizational performance can be calculated using the following formula:

$\begin{array}{rlrl}\mathrm{Kd} & = & \mathrm{r}^{2} \times 100 \% \\ & = & (0.759)^{2} \times 100 \% \\ = & 0.577 \times 100 \% \\ = & 57.7 \%\end{array}$

Based on these calculations, this means that $57.7 \%$ of activity budgeting affects organizational performance while other factors influence the remaining $42.3 \%$. Furthermore, to find out whether the effect of budgeting activities on organizational performance at Denpasar Bali City Government Bureau is significant or not, it is necessary to test its significance using the $t$ formula, which is as follows:

$$
\begin{aligned}
& \mathbf{t}=\frac{\mathbf{r} \sqrt{\mathbf{n}-2}}{\sqrt{1-\mathbf{r}^{2}}} \\
& \mathrm{t}=\frac{0,759 \sqrt{37-2}}{\sqrt{1-(0,759)^{2}}} \\
& \mathrm{t}=\frac{4,493}{0,651} \\
& \mathrm{t}=6,906
\end{aligned}
$$

From the results of the above calculations, the $t$ count value of 6.906 is obtained, then this value is compared with the table value for an error of 5\%, using a two-part test where $\mathrm{dk}=\mathrm{nk} ; 37-2=35$, and the table value is 2.021. Based on the results of these calculations, it can be stated that $\mathrm{t}$ count falls in the rejection area of Ho. So it can be concluded that the hypothesis is accepted, meaning that there is an influence between budgeting activities on organizational performance of 0.759 , which is a strong positive and significant, meaning that the coefficient can be applied to the entire population.

c. Hypothesis Testing 3

Before testing the multiple correlation hypothesis, the correlation between planning (X1) and activity budgeting (X2) is calculated with the formula:

$$
\begin{aligned}
\operatorname{rx} 1 \mathrm{x} 2 & =\frac{\sum x_{1} x_{2}}{\sqrt{\left(\sum x_{1}{ }^{2}\right)\left(\sum x_{2}{ }^{2}\right)}} \\
& =\frac{4,207}{\sqrt{(5,357)(5,619)}} \\
& =\frac{4,207}{\sqrt{30,100}}
\end{aligned}
$$




$$
\begin{aligned}
& \frac{4,207}{5,486} \\
= & 0,734
\end{aligned}
$$

Furthermore, to test the multiple correlations between planning (X1) and budgeting activities (X2) together on organizational performance (Y) with the following formula:

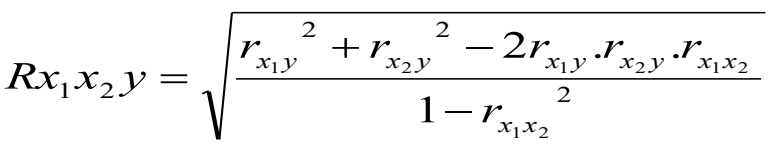

$$
\begin{aligned}
& R_{X_{1} X_{2} y}=\sqrt{\frac{(0,787)^{2}+(0,759)^{2}-2 \cdot(0,787) \cdot(0,759) \cdot(0,734)}{1-(0,734)^{2}}} R_{X_{1} X_{2} y}=\sqrt{\frac{(0,619)+(0,577)-0,877}{1-0,539}} \\
& R_{X_{1} X_{2} y}=\sqrt{\frac{1,196-0,877}{0,461}} \\
& R_{X_{1} X_{2} y}=\sqrt{\frac{0,319}{0,461}} \\
& R_{X_{1} X_{2} y}=\sqrt{0,691} \\
& R_{X_{1} X_{2} y}=0,831
\end{aligned}
$$

Based on the results of these calculations, the multiple correlation coefficient found is 0.831 . After consulting the previous interpretation guide table for this value, it is known that the multiple correlation coefficient is included in the very strong category because it is between the interval $(0.800-1,000)$. It shows that planning and budgeting activities together have a very strong positive influence on organizational performance at Denpasar Bali City Government Bureau. This effect applies to the entire population. The research will predict the influence of planning and budgeting activities on organizational performance, and it is done by calculating the coefficient of determination by squaring the correlation coefficient as follows:

$\begin{array}{rlr}\mathrm{Kd} & = & \mathrm{R}^{2} \times 100 \% \\ & = & (0.831)^{2} \times 100 \% \\ = & 0.691 \times 100 \% \\ = & 69.1 \%\end{array}$

It means that planning and budgeting activities of $69.1 \%$ together affect the organization's performance, and other factors influence the remaining 30.9\%. Furthermore, to test the significance of the multiple correlations between planning and budgeting activities together on organizational performance in its possibility to be applied to the entire population, the authors conducted a test by determining the Fount value, which was consulted with the Ftable value with the following formula: 


$$
\begin{aligned}
& \mathrm{F}_{\text {hit }}=\frac{R^{2} / k}{\left(1-R^{2}\right) /(n-k-1)} \\
& \mathrm{F}=\frac{(0,831)^{2} / 2}{\left(1-0,831^{2}\right) /(37-2-1)} \\
& \mathrm{F}=\frac{0,691 / 2}{0,309 / 34} \\
& \mathrm{~F}=\frac{0,345}{0,009} \\
& \mathrm{~F}=37,994
\end{aligned}
$$

So the obtained Fount value of 37.994 this value is then consulted with Ftable, for DK numerator $=2$ and dk denominator $=(37-2-1)=34$ obtained Ftable value at the error level set is $5 \%=3.28$. In this case, the provisions apply if the $\mathrm{F}$ count is greater than Ftable, then the multiple correlation coefficient tested is significant. That is, it can apply to the entire population. From the above calculation, it turns out that Fount > Ftable (37.994 > 3.28) shows that the multiple correlations are strong, positive, and significant and can be applied where the sample is taken. Furthermore, the hypothesis reads a strong and significant positive influence between planning and budgeting activities on organizational performance.

\section{d. Multiple Regression Analysis}

Multiple regression analysis was used to predict how much change the independent variable (planning and budgeting activities) had on the dependent variable (organizational performance) at Denpasar Bali City Government Bureau. Where the multiple regression analysis has expressed the equation:

$\mathrm{Y}=\mathrm{a}+\mathrm{b} 1 \mathrm{X} 1+\mathrm{b} 2 \mathrm{X} 2$

With the following formula:

$$
\begin{aligned}
b_{1} & =\frac{\left(\sum x_{1} y\right)\left(\sum x_{2}^{2}\right)-\left(\sum x_{1} x_{2}\right)\left(\sum x_{2} y\right)}{\left(\sum x_{1}{ }^{2}\right)\left(\sum x_{2}{ }^{2}\right)-\left(\sum x_{1} x_{2}\right)^{2}} b_{2}=\frac{\left(\sum x_{2} y\right)\left(\sum x_{1}^{2}\right)-\left(\sum x_{1} x_{2}\right)\left(\sum x_{1} y\right)}{\left(\sum x_{1}{ }^{2}\right)\left(\sum x_{2}{ }^{2}\right)-\left(\sum x_{1} x_{2}\right)^{2}} \\
a & =\frac{\sum Y-b_{1}\left(\sum X_{1}\right)-b_{2}\left(\sum X_{2}\right)}{n}
\end{aligned}
$$

From the helper table to calculate the multiple regression equation two predictors are obtained:

$$
\begin{aligned}
& \Sigma \mathrm{X} 1=153,600 \quad \Sigma \mathrm{X} 12=643.004 \\
& \Sigma X 1 . Y=647.573 \\
& \Sigma X 2=152,400 \quad \Sigma X 22=633,342 \Sigma X 2 . Y=642,498 \\
& \Sigma Y \quad=154,933 \quad \Sigma Y 2=654.578 \\
& \Sigma X 1 \cdot X 2=636,693
\end{aligned}
$$

Where:

$\Sigma x 1^{2}=\Sigma \mathrm{X} 12-(\Sigma \mathrm{X} 1) 2 / \mathrm{n}$ 


$$
\begin{aligned}
& =\quad 643,004-\frac{(153,600)^{2}}{37} \\
& =643,004-\frac{23592,960}{37} \\
& =643,004-637,648 \\
& =\quad 5,357 \\
& \Sigma x 22=\quad \Sigma X 22-(\Sigma X 2) 2 / \mathrm{n} \\
& =633,342-\frac{(152,400)^{2}}{37} \\
& =633,342-\frac{23225,760}{37} \\
& =633,342-627,723 \\
& =\quad 5,619 \\
& \Sigma y^{2}=\Sigma \mathrm{Y} 2-(\Sigma \mathrm{Y}) 2 / \mathrm{n} \\
& =\quad 654,578-\frac{(154,933)^{2}}{37} \\
& =\quad 654,578-\frac{24004,338}{37} \\
& =654,578-648,766 \\
& =\quad 5,812 \\
& \Sigma x 1 . x 2=\quad \Sigma \mathrm{X} 1 . \mathrm{X} 2-\frac{\left(\Sigma \mathrm{X}_{1}\right) \cdot\left(\Sigma \mathrm{X}_{2}\right)}{\mathrm{n}} \\
& =636,693-\frac{(152,400)(154,933)}{37} \\
& =636,693-\frac{23408,640}{37} \\
& =636,693-632,666 \\
& =\quad 4.027 \\
& \begin{aligned}
\Sigma x 1 . y & = & \Sigma X 1 \cdot Y-\frac{\left(\Sigma X_{1}\right) \cdot(\Sigma Y)}{n} \\
& = & 647,573-\frac{(153,600)(152,400)}{37} \\
& = & 647,573-\frac{643,183}{37} \\
& = & 647,573-643,183 \\
& = & 4,391
\end{aligned}
\end{aligned}
$$




$$
\begin{aligned}
& \Sigma \mathrm{x} 2 . \mathrm{y}=\quad \Sigma \mathrm{X} 2 . \mathrm{Y}-\frac{\left(\sum \mathrm{X}_{2}\right) \cdot(\Sigma \mathrm{Y})}{\mathrm{n}} \\
& =\quad 642,498-\frac{(152,400)(154,933)}{37} \\
& =\quad 642,498-\frac{23611,840}{37} \\
& =642,498-638,158 \\
& =\quad 4,340
\end{aligned}
$$

Furthermore, to calculate the prices or constant values (a), b1, and b2, the calculation is done with the following formula:

$$
\begin{aligned}
& b_{1}=\frac{\left(\sum x_{1} y\right)\left(\sum x_{2}^{2}\right)-\left(\sum x_{1} x_{2}\right)\left(\sum x_{2} y\right)}{\left(\sum x_{1}^{2}\right)\left(\sum x_{2}^{2}\right)-\left(\sum x_{1} x_{2}\right)^{2}} \\
& =\frac{(4,391) \cdot(5,619)-(4,027) \cdot(4,340)}{(5,357) \cdot(5,619)-(4,027)^{2}} \\
& =\frac{24,671-17,479}{30,100-16,220} \\
& =\frac{7,192}{13,880} \\
& =\quad 0.518 \\
& b_{2}=\frac{\left(\sum x_{2} y\right)\left(\sum x_{1}^{2}\right)-\left(\sum x_{1} x_{2}\right)\left(\sum x_{1} y\right)}{\left(\sum x_{1}{ }^{2}\right)\left(\sum x_{2}{ }^{2}\right)-\left(\sum x_{1} x_{2}\right)^{2}} \\
& \text { (4,340). (5,357)- (4,027). }(4,391) \\
& =\quad(5,357) \cdot(5,619)-(4,027)^{2} \\
& =\frac{23,249-17,683}{30,100-16,220} \\
& =\frac{5,566}{13,880} \\
& =\quad 0.401 \\
& a=\frac{\sum Y-b_{1}\left(\sum X_{1}\right)-b_{2}\left(\sum X_{2}\right)}{n} \\
& =\quad \frac{154,933-0,518(153,600)-0,401(152,400)}{37} \\
& =\frac{154,933-79,589-61,110}{37} \\
& =\frac{14,234}{37} \\
& =0.385
\end{aligned}
$$


Based on the results of these calculations obtained:

$\begin{array}{lll}\mathrm{a} & = & 0.385 \\ \mathrm{~b} 1 & = & 0.518 \\ \mathrm{~b} 2 & = & 0.401\end{array}$

From the value of the constant a and the regression coefficients b1 and b2 above, the regression equation can then be made, namely:

$$
\begin{aligned}
& =a+b 1 X 1+b 2 X 2 \\
& =0.385+0.518 \times 1+0.401 \times 2
\end{aligned}
$$

For the regression equation for planning and budgeting activities together on organizational performance are: $=0.385+0.518 \mathrm{X} 1+0.401 \mathrm{X} 2$. It means high and low organizational performance because the regression equation can predict planning and budgeting activities. Based on the data, the highest score for planning and budgeting activities is 75 ( $5 \times 15) .5$ is the highest score for each answer, and 15 is the number of question items. Therefore, organizational performance is:

$$
\begin{aligned}
& =0.385+0.518+0.401 \cdot 75 \\
& =0.385+68.936 \\
& =69,320
\end{aligned}
$$

It turns out that if the planning and budgeting of activities are increased to 75 units, the organizational performance will increase from 0.385 units to 69.320 units. It means that the better the planning and budgeting of activities, the higher the organizational performance at Denpasar Bali City Government Bureau. Based on the proposed hypothesis regarding the effect of planning and budgeting activities on organizational performance at Denpasar Bali City Government Bureau, it is necessary to discuss the existence of each variable. Based on the research results, the planning variable has a strong and significant positive influence with a correlation coefficient value of 0.787 , while the coefficient of determination $\left(r^{2}\right)$ is 0.619 , meaning that the planning variable contributes $61.9 \%$ in explaining organizational performance variables. As for the activity budgeting variable (X2) has a strong and significant positive influence on organizational performance, with a correlation coefficient of 0.759 . While the coefficient of determination $\left(\mathrm{r}^{2}\right)$ is 0.577 , meaning that the activity budgeting variable contributes $57.7 \%$ in explaining organizational performance.

The results of the simultaneous analysis show that planning and budgeting activities have a positive and significant effect on organizational performance with a correlation coefficient of 0.831 and the resulting contribution of influence $\left(\mathrm{r}^{2}\right)$ of $69.1 \%$ and the remaining $30.9 \%$ is determined by other factors outside the research model. Based on the preceding, the variables of planning and budgeting activities on organizational performance indicate that the magnitude of the influence of the variables quantitatively can be explained as follows:

1) The influence of the X1 (planning) variable on Y (organizational performance) needs to be analyzed by the author because planning is a decision-making process that has been carefully calculated about things that will be done in the future in an organization through goals, policies, procedures, standards, and budgets to achieve predetermined goals. 
2) The influence of the $X 2$ variable (activity budgeting) on $Y$ (organizational performance) needs to be analyzed by the author because activity budgeting is planning for the allocation of funds for the basic activities/operations of the organization through control, coordination and communication, performance appraisal and motivation in supporting activities and priorities to implementation of the functions, programs, and activities of the work unit concerned.

3) This study examines the effect of variables X1 (planning) and X2 (budgeting activities) on variable $\mathrm{Y}$ (organizational performance) to be analyzed. Organizational performance results from work that a person or group of people can achieve in the organization through indicators of inputs, outputs, results, benefits, and impacts. It follows the authority and responsibility to achieve organizational goals and does not violate the law and morals and ethics.

By identifying planning and budgeting activities, it will have an impact on organizational performance. According to the authors, based on the above thinking, the hypothesis states that planning and budgeting activities have a strong influence on organizational performance at Denpasar Bali City Government Bureau is acceptable. The magnitude of the influence of the two independent variables on the dependent variable also shows how to implement and improve organizational performance optimally; this fact has been answered by the existence of appropriate and accurate planning and budgeting activities.

Practically, the two variables run together, meaning that in planning and budgeting activities, they can become variables or factors that determine whether organizational performance is high or low. If the planning and budgeting of activities are carried out appropriately and accurately, the organizational performance will automatically increase. In this discussion, the author concludes that the two independent variables above show a significant influence, meaning that without proper and accurate planning and budgeting activities, the organizational performance at Denpasar Bali City Government Bureau cannot be improved or implemented optimally.

\section{Conclusion and Recommendation}

Based on the results of the research, which has been carried out to test the hypotheses and answers to the proposed problem formulation, the authors can draw the following conclusions; The results of the analysis of the effect of planning on organizational performance concluded that the effect indicated by the correlation coefficient $r$ of 0.787 was a strong positive correlation. It means that the more precise and accurate the planning, the more organizational performance will increase. At the same time, the coefficient of determination is obtained $61.9 \%$, and these results mean that the magnitude of the contribution of planning influences organizational performance, then the remaining $38.1 \%$ is caused by factors other.

The results of the analysis of the effect of budgeting activities on organizational performance concluded that the effect indicated by the correlation coefficient $r$ of 0.759 was a strong positive correlation. It means that the more precise and accurate the budgeting of activities, the higher the organizational performance, while the coefficient of determination is obtained at $57.7 \%$. These results mean that the magnitude of the contribution of the effect of budgeting activities on organizational performance, then the 
remaining $42.3 \%$ is due to other factors. The results of the joint analysis of the effect of planning and budgeting activities on organizational performance concluded that the effect indicated by the correlation coefficient $r$ of 0.831 is a very strong positive correlation. It means that the more precise and accurate the planning and budgeting of activities, the more organizational performance will increase. In contrast, the results of the coefficient of determination show $69.1 \%$, these results mean that the magnitude of the contribution of the influence of the planning and budgeting variables together on the performance organization then the remaining 30.9\% caused by other factors.

Recommendation: Based on the results of research and discussion in the conclusion above, the authors try to put forward suggestions that may be followed up, namely as follows; It is recommended that work planning be improved through setting work goals before carrying out activities which are the most basic organizational goals, determining work policies within the organization to direct leaders in decision making, and establishing work procedures that are by organizational conditions and handling future organizational activities. Budgeting activities in the organization are expected to be further improved through controlling expenditures so as not to be misdirected and not allocating expenditures to other fields. In addition, budget control must focus on budget expenditures on activities that are being carried out. For smooth activities, good coordination and communication are needed between work units within the organization so that the budgeting process can run smoothly. Organizational performance can be improved by implementing work activities guided by the applicable regulations within the organization, implementing effective and efficient work activities, and paying close attention to the speed of work activities so that organizational performance can increase significantly.

\section{References}

Alain, A. M. M., \& Melegy, M. M. A. H. (2017). Program and Performance Budgeting System in Public Sector Organizations: An Analytical Study in Saudi Arabian Context. International Business Research, 10(4), 157. https://doi.org/10.5539/ibr.v10n4p157

Bashaer, A., Singh, S., \& Sherine, F. (2016). Determinants of organizational performance: a proposed framework. International Journal of Productivity and Performance Management, 65, 844-859. https://doi.org/10.1108/IJPPM-02-2016-0038

Conţu, E. (2020). Organizational performance - theoretical and practical approaches; study on students' perceptions. Proceedings of the International Conference on Business Excellence, 14, 398-406. https://doi.org/10.2478/picbe-2020-0038

Creswell, J. W. (2013). Qualitative inquiry \& research design: Choosing among five approaches. In Sage (1st ed.). Pustaka Pelajar, Indonesia.

El Dahshan, M., Ismail Keshk, L., \& Dorgham, L. S. (2018). Talent Management and Its Effect on Organization Performance among Nurses at Shebin El -Kom Hospitals. International Journal of Nursing, 5(2), 108-123. https://doi.org/10.15640/ijn.v5n2a10

Farr, J., Hacker, J. S., \& Kazee, N. (2006). The policy scientist of democracy: The discipline of Harold D. Lasswell. American Political Science Review, 100(4), 579-587. https://doi.org/10.1017/S0003055406062459

Gulpenko, K., Tumashik, N., Filiasova, Y., \& Ritman, N. (2017). Budgeting fundamentals 
analysis for the purposes of organizational budgetary policy development. MATEC Web of Conferences, 106, 8102. https://doi.org/10.1051/matecconf/201710608102

Hanida, R. P., Irawan, B., \& Syamsurizaldi, S. (2015). the Analysis of Planning and Budgeting Policy for Making More Significant Local Government Planning Policy in Indonesia. IJASOS- International E-Journal of Advances in Social Sciences, 1(2), 287. https://doi.org/10.18769/ijasos.81928

Ishtiaq, M. (2019). Book Review Creswell, J. W. (2014). Research Design: Qualitative, Quantitative and Mixed Methods Approaches (4th ed.). Thousand Oaks, CA: Sage. English Language Teaching, 12(5), 40. https://doi.org/10.5539/elt.v12n5p40

Mohammadpour, B., Pahlevani, M., Makhdoomi Kaviri, S., \& Jain, P. (2016). Advanced slip mode frequency shifts islanding detection method for single-phase grid-connected PV inverters. Conference Proceedings - IEEE Applied Power Electronics Conference and Exposition - APEC, 2016-May(2), 378-385. https://doi.org/10.1109/APEC.2016.7467900

Özdem, G. (2011). An analysis of the mission and vision statements on the strategic plans of higher education institutions. Kuram ve Uygulamada Egitim Bilimleri, 11(4), 18871894.

Popova, V., \& Sharpanskykh, A. (2010). Modeling Organizational Performance Indicators. Information Systems, 35, 505-527. https://doi.org/10.1016/j.is.2009.12.001

Ramdany, \& Yadiati, W. (2018). Budgetary discipline \& factors that influence it: Study case in Ministries of Indonesia. Risk Governance and Control: Financial Markets \& Institutions, 8, 49-58. https://doi.org/10.22495/rgcv8i1art5

Risdwiyanto, A. (2017). High-Performance Organization untuk Menghadapi Turbulensi Lingkungan Bisnis. Jurnal Maksipreneur: Manajemen, Koperasi, Dan Entrepreneurship, 7, 73. https://doi.org/10.30588/jmp.v7i1.324

Stevcevska-Srbinoska, D. (2018). The Advantages of Budgets: A Survey of Macedonian Legal Entities. Business and Economic Research, 8(2), 33. https://doi.org/10.5296/ber.v8i2.12266

Taiwo, A., Lawal, F., \& Agwu, E. (2016). Vision and Mission in Organization: Myth or Heuristic Device? The International Journal Of Business \& Management, 4, 127.

Wargadinata, E. (2017). The Quality of Public Organization Performance Measurement. Sosiohumaniora, 19. https://doi.org/10.24198/sosiohumaniora.v19i2.11497 